第2日

第 3会場 1 階

(サファイア)

\section{0:10 10:55}

一般口演24

消化器 -4

\section{座長}

慶應義塾大学病院 予防医療センター

\section{井上詠 先生}

座長

一般財団法人 日本健康増進財団

三木一正先生

\section{2-1}

ラテックス免疫比濁法による血清ヘリコバク ター・ピロリ抗体価の比較検討

\author{
福岡県済生会 福岡総合病院 \\ ○池苗裕紊樽井里佳上村雄一郎 \\ 松永朋子 吉永 眞人 横田 真弓 \\ 藤木 貴子
}

\section{【目的】}

我が国での胃がんによる死亡者数は年問 5 万人前後で推 移しており、これは過去 35 年間あまり変化していない。 1983年に Helicobacter pylori (以下HP) が発見されて 以来、HPと胃がんの関連が明らかになり、HPを除菌 することにより胃がんの発生を約 $1 / 3 に$ 抑制可能である と報告されている。今回我々は HP 感染の有無を調べる 検查として、新たに開発されたラテックス免疫比濁法を 用い HP 感染の早期発見を目的に院内測定導入に向け比 較検討する機会を得たので報告する。

\section{【対象および方法】}

2016 年 8 月から 9 月の当院健診センター人間ドック受診 者で内視鏡検查を実施した血清梌体を対象とした。測定 機種は沉用自動分析装置：LABOSPECT008（日立）を 使用し、検討試薬は新たに開発されたラテックス免疫比 濁法による血清中抗 HP 抗体検出試薬 3 試薬を用い比較 検討を行った。判定不一致検体については従来の E プ レート（ELISA 法）で外部委託測定を実施した。

\section{【結果および考察】}

現段階にて対象となった87例の内視鏡所見は未感染 59 例、現感染 3 例、既感染（除菌捘例を含む）25例であっ た。未感染における抗 HP 抗体の不一致例は A：6 例 $(24 \%) 、 B ： 3$ 例 $(12 \%) 、 C ： 6$ 例 $(24 \%) 、$ 現感染の 不一致例は A : 1 例 $(23 \%) 、 B ： 3$ 例 $(100 \%) 、 C ： 1$ 例 $(23 \%)$ であった。一方、既感染の陽性例は A : 18例 $(72 \%) 、 B ： 4$ 例 $(16 \%) 、 C ： 12$ 例 $(48 \%)$ となり、試 薬によって判定に差が認められた。今後も引き続き検討 を行っていく。今回の検討により抗 HP 抗体の院内測定 が導入されれば、内視鏡検査との結果の併用により HP 感染の早期発見が可能であると考える。 


\section{2-2}

CLEIA法とLA法による血中Helicobacter pylori抗体検査結果とABC分類判定に及ぼ す影響

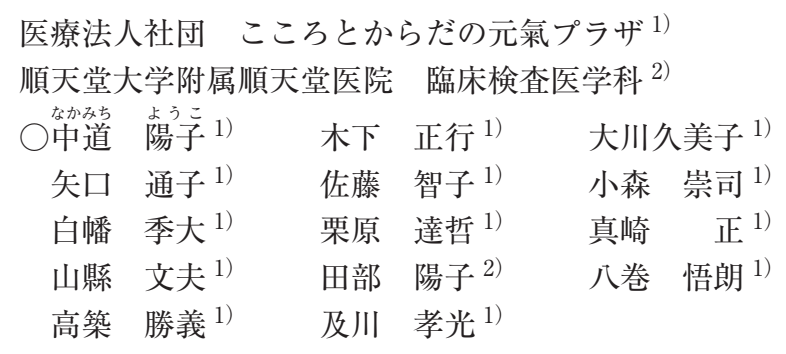

\section{【目的】}

化学発光酵素免疫測定法 (CLEIA) とラテックス凝集法 (LA)による血中 Helicobacter pylori (H.pylori) 抗体検査 について、検出結果の乘離の有無とともに、それぞれの 結果が $\mathrm{ABC}$ 分類（胃がんリスク判定）にどのように影 響するかを健康診断で得られた検体を用いて検討した。

\section{【対象】}

2016年 8 月に当施設において血中 H.pylori 抗体検查お よびペプシノーゲン（PG）検査を実施した人間ドック・ 健康診断受診者199例を対象とした。

\section{【方法】}

CLEIA 法による H.pylori 抗体検査および PG 検查には 【SphereLight Wako (和光純薬工業)】を用い、専用 試薬「スフィアライト $\mathrm{H}$ ピロリ抗体・J、ペプシノゲン I・II」を使用した。LA 法による H.pylori 抗体検查には 「LZテスト “栄研” H. ピロリ抗体」を用いた（カットオ フ值：CLEIA 法 $4 \mathrm{U} / \mathrm{mL} 、 \mathrm{LA}$ 法 $10 \mathrm{U} / \mathrm{mL}$ )。CLEIA 法と LA 法による H.pylori 抗体陽性率およびそれぞれの 結果を用いて得られた $\mathrm{ABC}$ 分類判定について比較、検 討した。

\section{【結果】}

H.pylori 抗体検查結果は、CLEIA 法では199例中27例 13.6 \% ) が陽性、LA 法では15例（7.5％）が陽性となっ た。CLEIA 法、LA 法ともに陽性となったのは13例（ 6.5 \%) であった。CLEIA 法のみ陽性であったのは14例、 $\mathrm{LA}$ 法のみ陽性は 2 例であった。 $\mathrm{ABC}$ 分類判定の一致 率は $92.0 \%$ であった。

\section{【考察】}

H.pylori 抗体検查において、CLEIA 法が LA 法に比べ、 陽性率が高くなった。原因としては、（1）カットオフ值 の相違、(2) 検出感度の違い、(3) 試薬中の抗原株の 違いが考えられる。近年、H.pylori 抗体検查は安価・簡 便な LA 法が主流だが、胃がんリスク判定検查としての $\mathrm{ABC}$ 分類に扔いては、偽陰性をいかに低減するかが重 要であり、より検出率の高いCLEIA 法の有用性が示唆 された。

\section{2-3}

\section{検査法の变更による血清ピロリ抗体価の経年 受信者に対する評価}

\author{
医療法人社団敬昭会 芙蓉診療所 成人病医学センター \\ ○渡辺かほる 円岡早苗杉山美和子 \\ 西牟田加奈子 原 千陽查美 \\ 藤崎 華佳 大坪 哲雄
}

\section{【目的】}

従来血清 H. ピロリ菌抗体検査は、EIA 法が主流であっ たが、ラテックス凝集比濁法に検査法を変更したことに より、経年受診者に対し判定不一致例を多数経験した。 除菌歴や内視鏡の検査結果も踏まえ、検査法による不一 致をどう考えるべきか検討した。

\section{【対象・方法】}

2015年 9 月 28 日 2016年 3 月 31 日までの人間ドック受 診者で経年的に血清 H. ピロリ菌抗体検査を実施した 1345名に対し、ラテックス凝集比濁法による抗体価と前 回值（EIA 法）との比較検討を行った。また、ラテッ クス凝集法で陽性だが、経年的に EIA 法にて陰性（3.0 未満）であった症例に対し再度 EIA 法にて再検を行っ た。

\section{【結果】}

判定一致率は $92.7 \%$ 、不一致率は $7.3 \%$ であった。不一致 の中でも、今回陽性で前回まで陰性（3.0未満）であっ た15例中 7 例に EIA 法で再検を行ったところ全て 3.0 未 満であった。

\section{【考察】}

2015年 9 月より、受注先の検査センターにおいて、ピロ リ検査の検査法の変更があった（EIA 法からラテック 又凝集比濁法）。経年受診者の多い当院では前回までの 結果值との不一致 (不一致率7.3\%) 例に対し、検査方 法の測定原理など充分に理解したうえで、受診者へ説 明を行い、別の検査法（UBT など）にての再検を勧め ていた。しかし、経年的に陰性（3.0未満）で、除菌歴 のない受診者に対しての説明に困穹し、従来法である EIA 法にて再検したところ、再検した 7 件全てが陰性 (3.0未満) であった。この結果を踏まえ、当院では従来 法の EIA 法を引き続き実施することにした。今回の検 討により、検査法の変更には充分な検討がなされ実施に 至っていることを考慮しつつも、自施設にあった検査法 を選択する必要性があると考えた。 


\section{2-4}

\section{血清H.pylori菌抗体価3.0 $9.9 \mathrm{U} / \mathrm{ml}$ の受 診者に対する胃X線検査でのH.pylori菌判定 の試み}

社会医療法人生長会 ベルクリニック

$\begin{array}{cccc}\text { 符妿 純子 } & \text { 婦木 祐市 } & \text { 出口 } & \text { 竜也 } \\ \text { 大家加奈子 } & \text { 吉田明里子 } & \text { 吉川 } & \text { 阿希 } \\ \text { 新井 桂介 } & \text { 園尾 広志 } & \text { 小林 } & \text { 亮 }\end{array}$

\section{【目的】}

健診に打ける H.pylori 菌（以下 Hp）感染のスクリーニ ング検査にはいくつかの方法があり、いずれも単体の検 查で Hp 感染の有無を確定することは困難である。単体 の検查で Hp 陰性判定を受けた受診者の中には、Hp 陽 性例が散見されるため、当施設は『Hp 陰性を確実に判 定する』方針を揭げている。その対策としては Hp 陽性 判定の精度が重要であるため、感染に対するグレーゾー ンである血清 $\mathrm{Hp}$ 抗体検查（以下血清抗体検查）で陰 性高值（3.0〜 $9.9 \mathrm{U} / \mathrm{ml} ）$ の受診者に対し、胃 X 線検査 が Hp 感染の判定にどの程度有用であるかを検討した。

\section{【対象】}

2015年 4 月～2016年 3 月に、当施設にて胃 X 線検查 と血清抗体検查を受診し、抗体值が $3.0 \sim 9.9 \mathrm{U} / \mathrm{ml}$ で便 中 $\mathrm{Hp}$ 抗原検查（以下 便中抗原検查）を施行した受診 者102名。(男性：42名、女性：60名、年齢31歳～80歳、 平均年齢45歳)。

\section{【方法】}

対象者の胃 X 線画像について、診療放射線技師 5 名、 医師 2 名が個別に背景粘膜判定を行い, Hp 陽性群に対 する感度・特異度を算出した。背景粘膜判定は中島・伊 藤らの方法に準拠したが、Hp 陽性を確実に拾い上げる よう判定の境界を多少変更した。

\section{【結果】}

便中抗原検查の Hp 陽性群（12名）に対して、胃 X 線 画像での Hp 陽性検出精度は、全評価者の平均值で感度 0.988、特異度 0.600 であった。

\section{【考察】}

今回の検討では、便中抗原検查の $\mathrm{Hp}$ 陽性群を評価者の ほほ全員が胃 X 線画像で Hp 陽性と判定した。このこ とより、スクリーニング検査における $\mathrm{Hp}$ 陽性の拾い上 げに対して、胃X 線画像の背景粘膜判定が有用な手段 になり得ると思われる。今後の課題は、血清抗体検查、 ペプシノーゲン検查、胃 X 線検査での比較検討を行い、 $\mathrm{Hp}$ 陽性の検出に対してょり有用な方策を模索すること である。

\section{2-5}

受診者の状態に適したピロリ菌検查実施への 取り組み〜多職種連携・協㗢における看護師 の役割

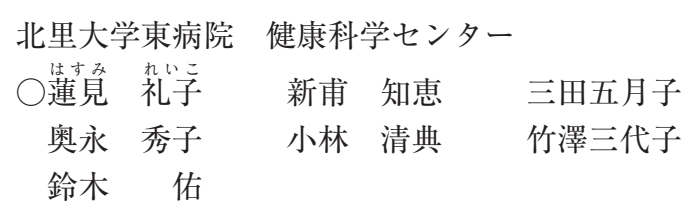

\section{【目的】}

当センターは平成 27 年度健診部門の移設拡大に伴い $\mathrm{ABC}$ 検診を導入した。開設当初ピロリ菌検査の方針が 定まっておらず、検查が適切に実施できないことがあ り、受診者の不利益につながった。そこで、健診当日に 簡易で安全に実施できる $\mathrm{ABC}$ 検診を推奨できないか考 えた。多職種に働きかけ $\mathrm{ABC}$ 検診を適切に推奖する取 り組みを行った。様々な混乱な時期を経験しながら多職 種連携・協働の必要性と看護師の役割について学んだた め報告する。

\section{【対象】}

当センター職員。

\section{【方法】}

平成 27 年 5 月〜平成 28 年 3 月までの $\mathrm{ABC}$ 検診導入の取 り組みを、タックマンモデルの 4 つのプロセスから検証し、 多職種連携・協働の必要性と看護師の役割を振り返る。

\section{【結果】}

形成期：ピロリ菌検查に対する認識が異なり、各職種に よる判断で検查を実施していた。混乱期：ABC 検診を 実施する受診者は増加したが、各職種からは「手間が増 えた、混乱する」などの意見が対立した。統一期 : 看護 師が各職種に働きかけ、毎日ミーティングを実施した。 各職種の業務状況を扔互いが理解することで、チーム内 の関係性が安定へと向かった。 $\mathrm{ABC}$ 検診を適切に推奨 することが多職種間での目的であると共通理解した。機 能期:ピロリ菌に対する検查の方向性が確立したことで、 $\mathrm{ABC}$ 検診を適切に運用できるようになった。

\section{【考察】}

タックマンモデルの示す 4 つのステップは、チームを形 成する上では必要な過程である。今回 $\mathrm{ABC}$ 検診の推奨 に向け生じた混乱期の緊張や衝突は、チームが成り立つ 上で必要なプロセスであったと考える。統一期におけ る看護師の各職種への働きかけは調整役としての役割を 担っており、今後は 4 つのステップを効率よく進めてい く上で、看護師は形成期から調整役として役割をとるこ とが望ましい。 